\title{
Lysophospholipids increase ICAM-1 expression in HUVEC through a Gi- and NF-\{kappa $\}$ B-dependent mechanism \\ Hsinyu Lee, Chi Iou Lin, Jia-Jun Liao, Yu-Wei Lee, Hsi Yuan Yang, Chung-Ying \\ Lee, Hsien-Yeh Hsu and Hua Lin Wu \\ Am J Physiol Cell Physiol 287:1657-1666, 2004. First published Aug 4, 2004; \\ doi:10.1152/ajpcell.00172.2004
}

You might find this additional information useful...

This article cites 56 articles, 22 of which you can access free at:

http://ajpcell.physiology.org/cgi/content/full/287/6/C1657\#BIBL

This article has been cited by 3 other HighWire hosted articles:

Rho Kinase Inhibition by Fasudil Ameliorates Diabetes-Induced Microvascular Damage

R. Arita, Y. Hata, S. Nakao, T. Kita, M. Miura, S. Kawahara, S. Zandi, L. Almulki, F. Tayyari,

H. Shimokawa, A. Hafezi-Moghadam and T. Ishibashi

Diabetes, January 1, $2009 ; 58$ (1): 215-226.

[Abstract] [Full Text] [PDF]

Carbamylated Low-Density Lipoprotein Induces Monocyte Adhesion to Endothelial Cells Through Intercellular Adhesion Molecule-1 and Vascular Cell Adhesion Molecule-1

E. O. Apostolov, S. V. Shah, E. Ok and A. G. Basnakian

Arterioscler. Thromb. Vasc. Biol., April 1, 2007; 27 (4): 826-832.

[Abstract] [Full Text] [PDF]

Protein kinase D2 mediates lysophosphatidic acid-induced interleukin 8 production in nontransformed human colonic epithelial cells through NF-\{kappa\}B

T. T. Chiu, W. Y. Leung, M. P. Moyer, R. M. Strieter and E. Rozengurt

Am J Physiol Cell Physiol, February 1, 2007 ; 292 (2): C767-C777.

[Abstract] [Full Text] [PDF]

Updated information and services including high-resolution figures, can be found at:

http://ajpcell.physiology.org/cgi/content/full/287/6/C1657

Additional material and information about AJP - Cell Physiology can be found at: http://www.the-aps.org/publications/ajpcell

This information is current as of May 13, 2009 .

AJP - Cell Physiology is dedicated to innovative approaches to the study of cell and molecular physiology. It is published 12 times a year (monthly) by the American Physiological Society, 9650 Rockville Pike, Bethesda MD 20814-3991. Copyright () 2005 by the American Physiological Society. ISSN: 0363-6143, ESSN: 1522-1563. Visit our website at http://www.the-aps.org/. 


\title{
Lysophospholipids increase ICAM-1 expression in HUVEC through a $\mathrm{G}_{\mathrm{i}^{-}}$and NF-кB-dependent mechanism
}

\author{
Hsinyu Lee, ${ }^{1,2}$ Chi Iou Lin, ${ }^{2}$ Jia-Jun Liao, ${ }^{1}$ Yu-Wei Lee, ${ }^{2}$ \\ Hsi Yuan Yang, ${ }^{3}$ Chung-Ying Lee, ${ }^{3}$ Hsien-Yeh Hsu, ${ }^{4}$ and Hua Lin $\mathrm{Wu}^{5}$ \\ ${ }^{1}$ Department of Life Science, Institutes of ${ }^{2}$ Zoology and ${ }^{3}$ Molecular and Cellular Biology, National Taiwan University, \\ Taipei, Taiwan 106; ${ }^{4}$ Faculty of Medical Technology, Institute of Biotechnology in Medicine, National Yang-Ming University, \\ Taipei, Taiwan 112; and ${ }^{5}$ Institute of Biochemistry, National Cheng Kung University, Tainan, Taiwan 701, Republic of China
}

Submitted 1 April 2004; accepted in final form 3 August 2004

\begin{abstract}
Lee, Hsinyu, Chi Iou Lin, Jia-Jun Liao, Yu-Wei Lee, Hsi Yuan Yang, Chung-Ying Lee, Hsien-Yeh Hsu, and Hua Lin Wu. Lysophospholipids increase ICAM-1 expression in HUVEC through a $\mathrm{G}_{\mathrm{i}^{-}}$ and NF-кB-dependent mechanism. Am J Physiol Cell Physiol 287: C1657-C1666, 2004. First published August 4, 2004; doi:10.1152/ ajpcell.00172.2004.-Lysophosphatidic acid (LPA) and sphingosine 1-phosphate $(\mathrm{S}-1-P)$ are both low molecular weight lysophospholipid (LPL) ligands that are recognized by the Edg family of $\mathrm{G}$ proteincoupled receptors. In endothelial cells, these two ligands activate Edg receptors, resulting in cell proliferation and cell migration. The intercellular adhesion molecule-1 (ICAM-1, CD54) is one of many cell adhesion molecules belonging to the immunoglobulin superfamily. This study showed that LPA and S-1-P enhance ICAM-1 expression at both the mRNA and protein levels in human umbilical cord vein endothelial cells (HUVECs). This enhanced ICAM-1 expression in HUVECs was first observed at $2 \mathrm{~h}$ postligand treatment. Maximal expression appeared at $8 \mathrm{~h}$ postligand treatment, as detected by flow cytometry and Western blotting. Furthermore, the effects of S-1-P on ICAM-1 expression were shown to be concentration dependent. Prior treatment of HUVECs with pertussis toxin, a specific inhibitor of $G_{i}$, ammonium pyrrolidinedithiocarbamate and BAY 11-7082, inhibitors of the nuclear factor (NF)-кB pathway, or Clostridium difficile toxin $\mathrm{B}$, an inhibitor of Rac, prevented the enhanced effect of LPL-induced ICAM-1 expression. However, pretreatment of HUVECs with exoC3, an inhibitor of Rho, had no effect on S-1-P-enhanced ICAM-1 expression. In a static cell-cell adhesion assay system, pretreatment of LPL enhanced the adhesion between HUVECs and U-937 cells, a human mononucleated cell line. The enhanced adhesion effect could be prevented by preincubation with a functional blocking antibody against human ICAM-1. These results suggest that LPLs released by activated platelets might enhance interactions of leukocytes with the endothelium through a $\mathrm{G}_{\mathrm{i}^{-}}, \mathrm{NF}-\kappa \mathrm{B}-$, and possibly Rac-dependent mechanism, thus facilitating wound healing and inflammation processes.
\end{abstract}

lysophosphatidic acid; sphingosine 1-phosphate; inflammation; intercellular adhesion molecule-1; nuclear factor- $\mathrm{B}$; human umbilical cord vein endothelial cells

LYSOPHOSPHATIDIC ACID (LPA) and sphingosine 1-phosphate (S-1-P), low molecular weight LPLs with diverse biological activities $(18,33,44)$, are generated by enzymatic cleavage of membrane phospholipids. Recent evidence suggests that autotoxin, a previously identified exoenzyme, might be responsible for the generation of these two phospholipids (4). In serum, LPA and S-1-P reach micromolar concentrations and account for much of the cellular growth effects of serum $(12,46,55)$.

Address for reprint requests and other correspondence: H. Lee, Dept. of Life Science and Institute of Zoology, National Taiwan Univ., Taipei, Taiwan 106, ROC (E-mail: hsinyu@ntu.edu.tw).
LPA and S-1-P are enriched in activated platelets, injured cells, and ovarian cancer cells, suggesting potential roles in inflammatory, wound-healing, and tumor-formation events $(18,43$, $47,52,54,55)$.

The cellular signals of LPA and S-1-P are transduced by two subfamilies of G protein-coupled receptors (GPCRs) encoded by endothelial differentiation genes (Edg Rs; see Refs. 2, 5, 21, $34,45)$. Human Edg1 (S-1- $\left.P_{1}\right)$, Edg3 (S-1- $\left.P_{3}\right)$, Edg5 (S-1- $\left.P_{2}\right)$, Edg6 (S-1- $\left.P_{4}\right)$, and Edg8 (S-1- $\left.P_{5}\right)$ transduce signals for S-1-P. Human Edg2 $\left(\mathrm{LPA}_{1}\right)$, Edg4 $\left(\mathrm{LPA}_{2}\right)$, and Edg7 $\left(\mathrm{LPA}_{3}\right)$ transduce signals for LPA. Multiple signaling pathways are activated by Edg receptors, which have been characterized in heterologous expression systems, including ras-dependent activation of Erk 1/2, increases in intracellular $\mathrm{Ca}^{2+}$ concentration, and recruitment of rho GTPase and its downstream targets $(2,5,21,34,45)$.

Endothelial cells form the inner lining of blood vessels and participate in important physiological processes, including materials exchange, coagulation, and wound healing. Several pathological phenotypes, including atherosclerosis, inflammation, and cancer, are associated with excessive activation or abnormalities of endothelial cells (15). Endothelial cells express at least three types of Edg receptors, including Edg1, Edg 2, and Edg3 (26). LPA and S-1-P regulate several endothelial functions, including proliferation, migration, and secretion of proteases $(4,26,36,37)$. It has also been suggested that these lipids might also play a role in the regulation of angiogenesis and blood vessel integrity $(4,28,29,31)$.

The mechanisms by which vascular endothelial cells capture circulating lymphocytes are well documented, and several endothelial cell receptors responsible for these interactions have been described. Among these molecules, intercellular adhesion molecule 1 (ICAM-1; CD54) is one of the most characterized adhesion molecules expressed on endothelial cells. ICAM-1 interacts with LFA-1 and Mac-1, members of the $\beta_{2}$-integrin family, which are expressed on activated lymphocytes. Interactions among LFA-1, Mac-1, and ICAM-1 are responsible for the firm interaction between leukocytes and endothelial cells and therefore are important for subsequent processes.

ICAM-1 is constitutively expressed in the microvasculature but not in large arteries or veins. However, in atherosclerotic arteries, ICAM-1 expression is elevated in the endothelium covering atherosclerotic plaques $(9,48)$. Abnormal interactions

The costs of publication of this article were defrayed in part by the payment of page charges. The article must therefore be hereby marked "advertisement" in accordance with 18 U.S.C. Section 1734 solely to indicate this fact. 
between monocytes and endothelial cells have been suggested to be one of the early events in the generation of atherosclerotic plaque and also are necessary for wound healing $(17,40)$. Both pretreatment of human saphenous veins with anti-ICAM-1 antibodies and pretreatment of monocytes with anti- $\beta_{2}$-integrins significantly reduced monocyte adhesion to these vessels (7). Those observations suggest that abnormal ICAM-1 expression might be an important indicator of atherosclerosis.

Expression of ICAM-1 on endothelial cells is upregulated by inflammatory cytokines such as interleukin (IL)- $1 \beta$ and tumor necrosis factor (TNF)- $\alpha$, and also by plasma lipoprotein such as oxidized low-density lipoproteins (LDLs; see Refs. 11, 14, $24,41)$. Because LPA and S-1-P stimulate the expression of these inflammatory cytokines from macrophages (27), and LPA is generated along with oxidized LDLs $(13,32,42)$, we hypothesized that LPA and S-1-P may affect endothelial cell interactions with leukocytes through modulating the expression of ICAM-1. In this report, we present evidence that LPA and S-1-P enhance ICAM-1 expression in human umbilical cord vein endothelial cells (HUVECs) in a time- and concentration-dependent fashion. Furthermore, by using chemical inhibitors, we show that LPA and S-1-P enhance ICAM-1 expression through a $\mathrm{G}_{\mathrm{i} / \mathrm{o}^{-}}$, nuclear factor $(\mathrm{NF}) \mathrm{-} \mathrm{KB}$ - and possibly Rac-dependent and Rho-independent mechanism, which is consistent with the signaling pathways activated by LPLs binding to Edg receptors. In addition, the adhesion between U-937 human mononucleated cells and HUVECs is enhanced by LPL treatment. This enhancement is likely because of an increase in ICAM-1 expression in HUVECs, since the enhancement is prevented by pretreatment with functional blocking antibody against human ICAM-1. These results imply that the inflammatory effects of LPL are likely mediated through the enhancement of ICAM-1 expression.

\section{MATERIALS AND METHODS}

Reagents and antibodies. S-1-P was purchased from Biomol (Plymouth, PA). LPA, fatty acid-free BSA, and Clostridium difficile toxin B (Toxin B) were purchased from Sigma (St. Louis, MO). Pertussis toxin (PTx) and BAY 11-7082 (BAY) were from CalBiochem (La Jolla, CA). The C3 exoenzyme was purchased from List Biological Laboratory (Campbell, CA).

Human ICAM-1 antibody (clone M19), FITC-conjugated mouse anti-human ICAM-1 monoclonal antibody (clone 6.5B5), and functional blocking anti-human ICAM-1 monoclonal antibody (clone 15.2) were purchased from Santa Cruz Biotechnology (Santa Cruz, CA). Horseradish peroxidase-conjugated goat anti-mouse IgG was obtained from Boehringer Mannheim (Indianapolis, IN). FBS and M199 were purchased from Hyclone (Logan, UT). RPMI-1640 medium and trypsin were purchased from GIBCO-BRL (Grand Island, NY). Endothelial cell growth medium (EGM) was purchased from Cell Applications (San Diego, CA). Penicillin, streptomycin, and L-glutamine were purchased from Invitrogen (Carlsbad, CA).

Cell culture. HUVECs were isolated from fresh umbilical cords by treatment with $1 \%(\mathrm{vol} / \mathrm{vol})$ collagenase in PBS at $37^{\circ} \mathrm{C}$ for $10 \mathrm{~min}$. After elution with M199 containing 20\% FCS, HUVECs were cultured on $0.04 \%$ gelatin-coated (Sigma) $10-\mathrm{cm}$ plates in M199 supplemented with $100 \mathrm{U} / \mathrm{ml}$ penicillin, $100 \mathrm{mg} / \mathrm{ml}$ streptomycin, $2 \mathrm{mM}$ L-glutamine (Invitrogen), 10\% (vol/vol) FBS, and $25 \%$ (vol/vol) EGM, and cells underwent one passage weekly. Cells were subcultured after trypsinization [0.5\% ( vol/vol) trypsin solution, supplemented with $0.2 \%$ ( $\mathrm{vol} / \mathrm{vol})$ EDTA] and used throughout passages 2 to 4. The human leukemic monoblast cell line, U-937 (CRL1593), was purchased from ATCC (American Type Culture Collection, Manas- sas, VA) and cultured in RPMI-1640 medium [supplemented with $0.2 \%$ (wt/vol) $\mathrm{NaHCO}_{3}$ and $0.03 \%$ (wt/vol) L-glutamine] containing $100 \mathrm{U} / \mathrm{ml}$ penicillin, $100 \mathrm{mg} / \mathrm{ml}$ streptomycin, and $10 \%$ (vol/vol) FBS. Unless otherwise indicated, all cultures were grown at $37^{\circ} \mathrm{C}$ in a humidified atmosphere containing $5 \% \mathrm{CO}_{2}$ in $175-\mathrm{cm}^{2}$ culture flasks. U-937 cell stocks were maintained by subculturing cells every 4 th or 5 th day in fresh medium at a seeding density of $0.5 \times 10^{5}$ cells $/ \mathrm{ml}$ (subculturing was performed earlier if the cell density exceeded $1.5 \times$ $10^{5}$ cells $\left./ \mathrm{ml}\right)$.

$R T-P C R$ for ICAM-1. Total cellular RNA was extracted from HUVECs by the Tri-Zol reagent (GIBCO-BRL), and a Superscript kit (GIBCO-BRL) was used for the RT synthesis of cDNA. PCR amplification was performed with 35 cycles of $30 \mathrm{~s}$ at $94^{\circ} \mathrm{C}, 30 \mathrm{~s}$ at $62^{\circ} \mathrm{C}$, and $2 \mathrm{~min}$ at $72^{\circ} \mathrm{C}$. Oligonucleotides pairs were $5^{\prime}$-dGCAAGCTCCCAGTGAAATGCAAAC and 5'-dTGTCTACTGACCCCAACCCTTGATG for human ICAM-1. A 498-bp product was expected in the reaction. The primers used to amplify GAPDH were 5'-dACCACAGTTCATGCCATCAC and 5'-dTCCACCACCCTGTTGCTGTA. A 450-bp product was expected in the reaction. PCR products were resolved on $2 \%$ agarose gels, stained with ethidium bromide, and photographed.

Semiquantitative RT-PCR. To assess the levels of ICAM-1 mRNA in HUVECs, RT-PCR results were scanned using a PhosphoreImager and analyzed by ImageQuaNT software (Amersham Biosciences, Piscataway, NJ). Human GAPDH from the same sample in the RT-PCR was used as an internal control to correct the loading.

FACscan. Subconfluent cultures of HUVECs were serum starved with or without chemical inhibitors for $16 \mathrm{~h}$ and incubated with LPA or S-1-P for the indicated durations at $37^{\circ} \mathrm{C}$. Suspensions of $10^{6}$ HUVECs in a $50-\mu 1$ volume of PBS with $0.1 \%$ fatty acid-free BSA received $20 \mu \mathrm{l}$ FITC-conjugated human anti-ICAM-1 (clone 6.5B5) and were incubated for $30 \mathrm{~min}$ at $4^{\circ} \mathrm{C}$. Antibody binding of HUVECs with and without stimulation was determined by CyFlow SL (Partec, Germany) and analyzed by WinMDI version 2.7 software.

Western blotting for ICAM-1. Endothelial cells plated in six-well plates were treated with the indicated concentrations of LPA or S-1-P. Treated cells were then lysed with RIPA buffer $(150 \mathrm{mM} \mathrm{NaCl}, 1.0 \%$ Nonidet P-40, 0.5\% deoxycholate, $0.1 \%$ SDS, and $50 \mathrm{mM}$ Tris, $\mathrm{pH}$ 8.0) containing protease inhibitor cocktail (Sigma) and $2 \mathrm{mM}$ sodium vanadate. Equal amounts of cell lysates were separated by $\sim 4-10 \%$ SDS-PAGE and electrophoretically transferred to Immobilon membranes. The transferred membranes were blocked with blocking buffer $(\mathrm{PBS}+0.1 \%$ Tween 20 with $1 \% \mathrm{BSA})$ at room temperature for $1 \mathrm{~h}$. The membranes were immunoblotted with anti-human ICAM-1 monoclonal antibody for $2 \mathrm{~h}$ and then washed in washing buffer $(0.1 \%$ Tween 20, without $1 \%$ BSA) one time for 15 min followed by two washes for $5 \mathrm{~min}$. The membranes were blocked again in new blocking buffer for $1 \mathrm{~h}$ at room temperature and then immunoblotted with appropriate horseradish peroxidase-conjugated secondary antibodies for $1 \mathrm{~h}$. Membranes were subsequently washed in washing buffer one time for $15 \mathrm{~min}$ followed by two washes for $5 \mathrm{~min}$ each. Proteins on each immunoblot were visualized with Renaissance Western blot chemiluminescence reagent (NEN Life Science, Boston, MA). Blots were stripped and reprobed with an antibody against human actin to demonstrate uniform loading of proteins.

Immunofluorescence staining. HUVECs were grown and treated on glass coverslips at $37^{\circ} \mathrm{C}$. After being fixed in methanol $\left(-20^{\circ} \mathrm{C}\right)$ for 5 min and air-dried, $50 \mu \mathrm{l}$ of mouse anti-human ICAM-1 monoclonal antibody $(4.5 \mathrm{~g} / \mathrm{ml}$ in $0.5 \%$ FBS- $0.5 \%$ Tween 20-PBS) were applied as the primary antibody solution and incubated overnight at $4{ }^{\circ} \mathrm{C}$ in a humidified chamber. After extensive rinsing with PBS, the coverslips were incubated with $50 \mu \mathrm{l}$ of Cy3-conjugated goat anti-mouse IgG (DAKO, Carpinteria, CA) as the secondary antibody (1:20 in $0.5 \%$ FBS- $0.5 \%$ Tween 20-PBS) for $2 \mathrm{~h}$ at $37^{\circ} \mathrm{C}$. After three washes with PBS, cell nuclei were counterstained with $4^{\prime}, 6^{\prime}$-diamidino-2-phenylindole (1:5,000 in $0.5 \%$ FBS- $0.5 \%$ Tween 20-PBS) purchased from Sigma. Glass coverslips were subsequently washed three times 
A

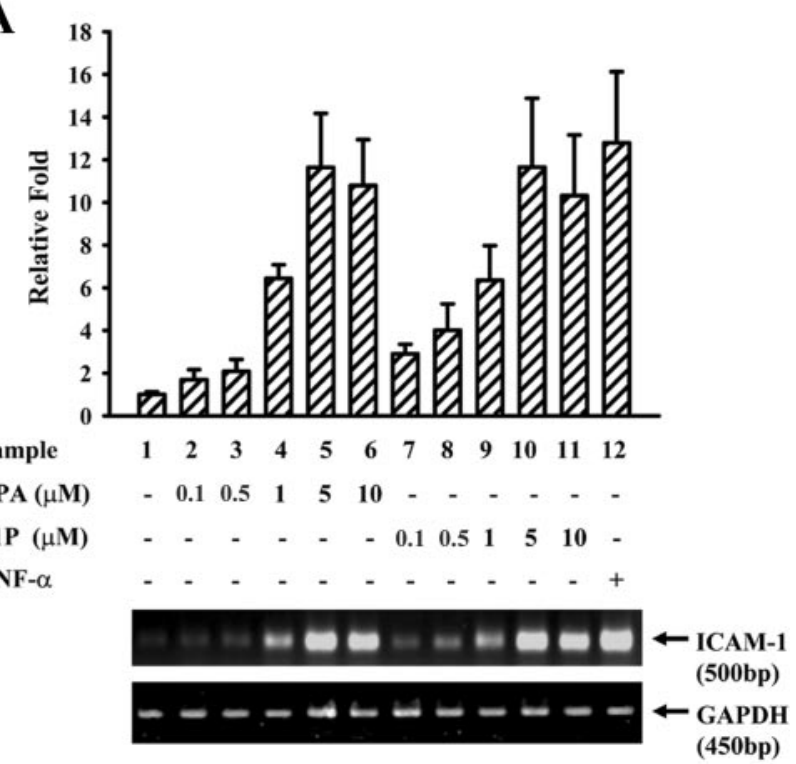

B
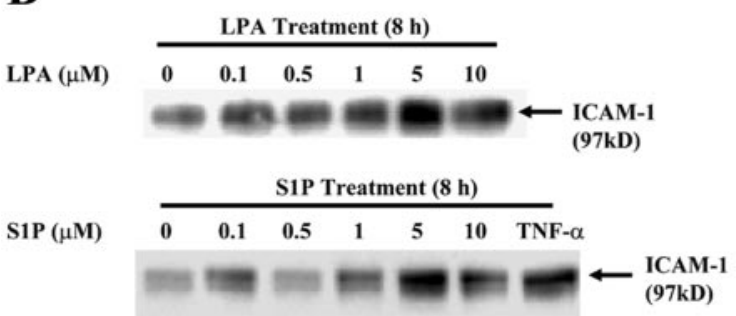

Fig. 1. Lysophosphatidic acid (LPA) and sphingosine 1-phosphate (S-1-P) upregulate intercellular adhesion molecule (ICAM)-1 expression in human umbilical vein endothelial cells (HUVECs) in a dose-dependent manner. A: HUVECs were incubated with LPA or S-1-P for $4 \mathrm{~h}$ at various concentrations, as indicated. RNAs from treated cells were harvested and subjected to RT-PCR reactions using specific primer sets for human ICAM-1 or GAPDH. The reaction products were separated on $2 \%$ agarose gels and photographed. TNF- $\alpha$ was used as the positive control. Similar experiments were repeated three times, and a representative result is shown. Histograms represent quantification of RT-PCR corrected with GAPDH and analyzed by PhosphorImager using ImageQuaNT software. All data are relative multiples of expression compared with untreated cells. $B$ : HUVECs were incubated with LPA (top) and S-1-P (bottom) for $8 \mathrm{~h}$ at various concentrations, as indicated. Total cell lysates were isolated, and ICAM-1 protein expression levels were monitored by Western blotting. Similar experiments were repeated three times, and a representative result is shown.

with double-distilled water, mounted with Fluoromount G (Electron Microscopy Sciences, Washington, PA), and examined using a confocal microscope.

Confocal microscopy. To examine the distribution of ICAM-1, immunostained cells were mounted with Immunomount G. Cells were observed using a laser-scanning confocal microscope (Leica model TCS SP2) with a Leica Mellis-Griot $\times 63$ numerical aperture oil immersion objective, with a pinhole of 1.5 and an electronic zoom of 1.5 or 2 . Cy3 was excited using a $543-\mathrm{nm}$ argon/krypton laser and detected with an $\sim 550$ - to 620 -nm band-pass filter. Images were manipulated with a Leica TCS SP2 scanner.

Assay for U-937 adhesion to treated endothelium. HUVECs cultured in six-well plates were stimulated for $8 \mathrm{~h}$ with $5 \mu \mathrm{M}$ LPA or S-1-P. After being gently washed three times with M199, U-937 monocytes $\left(1 \mathrm{ml}, 5 \times 10^{6}\right.$ cells $\left./ \mathrm{ml}\right)$ were added to the cultures and then incubated at $37^{\circ} \mathrm{C}$ for $1 \mathrm{~h}$. In the inhibitory experiments, antihuman ICAM-1 functional blocking antibodies $(10 \mu \mathrm{g} / \mathrm{ml})$ or normal mouse IgG was added before the addition of U-937 monocytes.
Cultures were then washed by placing $1 \mathrm{ml}$ of M199 gently on the cultures three to five times until no visible suspension of U-937 cells was observed. After being washed, cell cultures were imaged by microscopy with a Kodak digital camera, and the number of monocytes per culture was counted.

Statistical analysis. Significant differences between treatment groups were tested using ANOVA followed by Duncan's new multiple range test (StatView; Abacus Concept, Berkeley, CA). Each experiment was repeated at least three times. A value of $P<0.05$ was considered statistically significant.

\section{RESULTS}

LPA and S-1-P increase ICAM-1 mRNA in HUVECs. By DNA array analysis, we found that several genes that participate in inflammatory processes are upregulated by both LPA and $\mathrm{S}-1-P$ treatments. To confirm these observations, we determined the expression of ICAM-1 mRNA in LPL-treated HUVECs by RT-PCR. As shown in Fig. 1A, middle, and Fig. $2 A$, middle, ICAM-1 mRNA levels increased in both LPA- and S-1-P-treated samples in a concentration (Fig. 1A)- and time (Fig. 2A)-dependent manner. The expression patterns of GAPDH, which was used as the loading control, did not differ significantly in either LPA- or S-1- $P$-treated samples (Figs. $1 A$ and $2 A$, bottom). The RT-PCR results were quantified and are
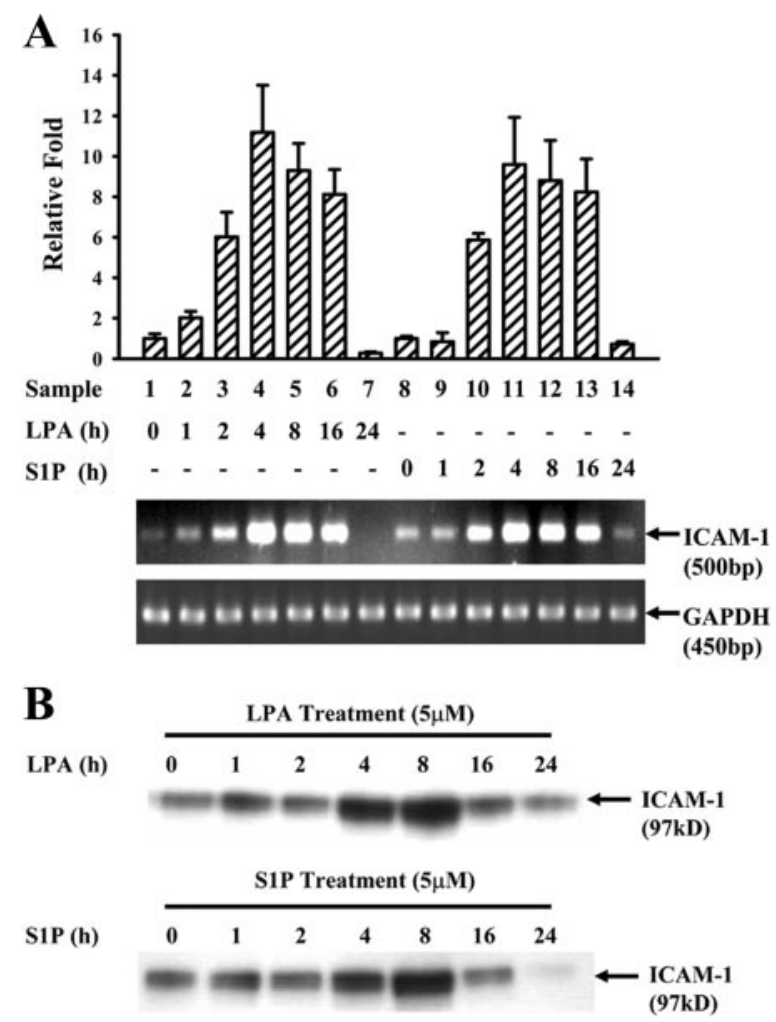

Fig. 2. LPA and S-1-P upregulate ICAM-1 expression in HUVECs in a time-dependent manner. A: HUVECs were incubated with LPA $(5 \mu \mathrm{M})$ or S-1-P $(5 \mu \mathrm{M})$ for various times, as indicated. RNAs were analyzed as in Fig. $1 \mathrm{~A}$. Similar experiments were repeated three times, and a representative result is shown. Histograms represent quantification of RT-PCR corrected with GAPDH analyzed by PhosphorImager using ImageQuaNT software. All data are relative multiples of expression compared with untreated cells. $B$ : HUVECs were incubated with $5 \mu \mathrm{M}$ LPA (top) or S-1-P (bottom) at various times, as indicated. Total cell lysates were isolated, and ICAM-1 protein expression levels were monitored by Western blotting. Similar experiments were repeated three times, and a representative result is shown. 
ICAM-1
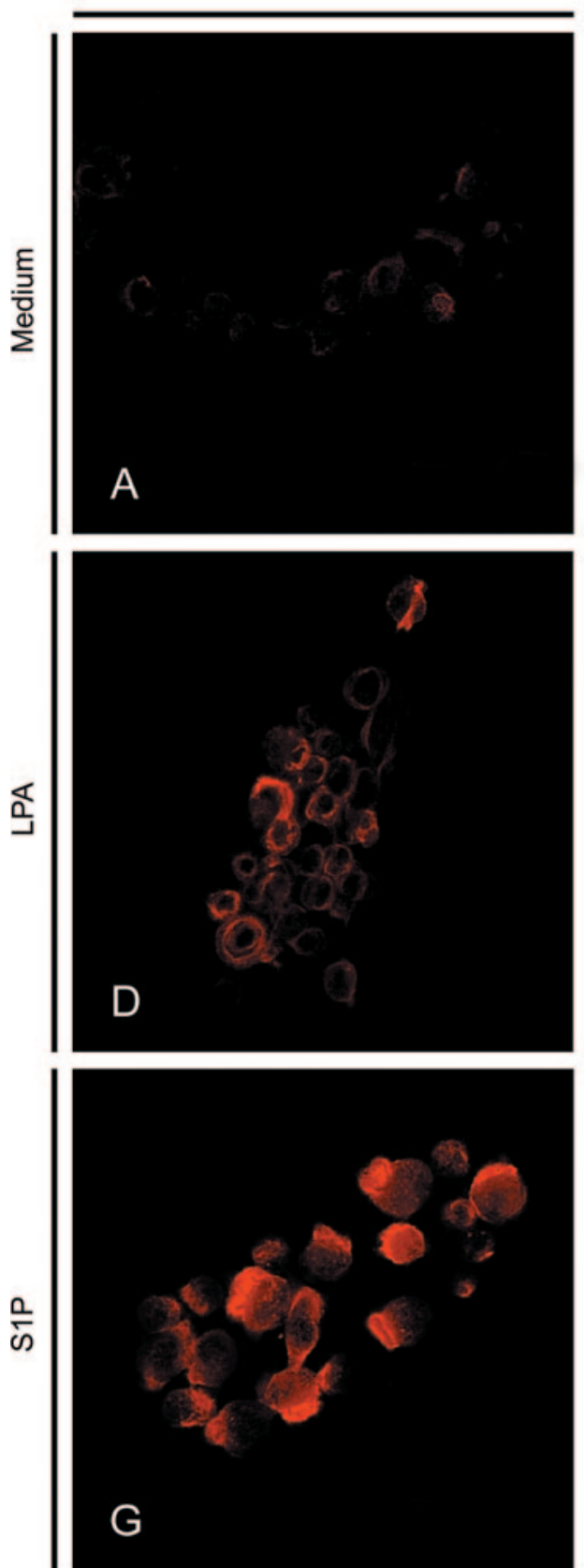

DAPI
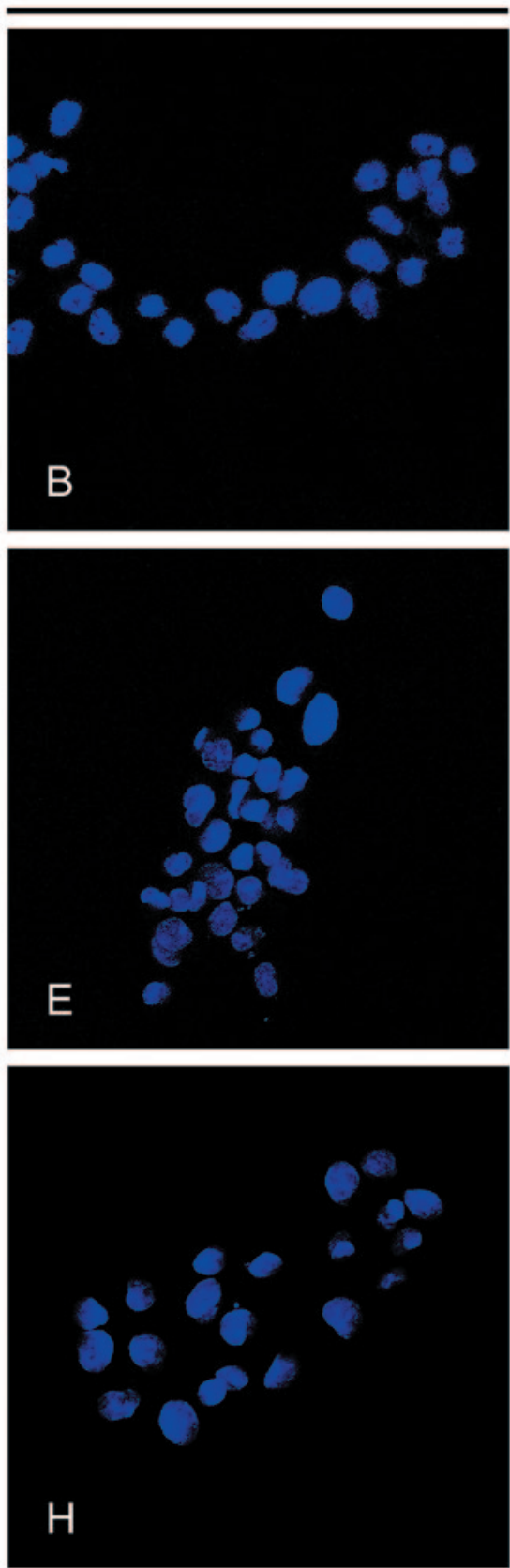
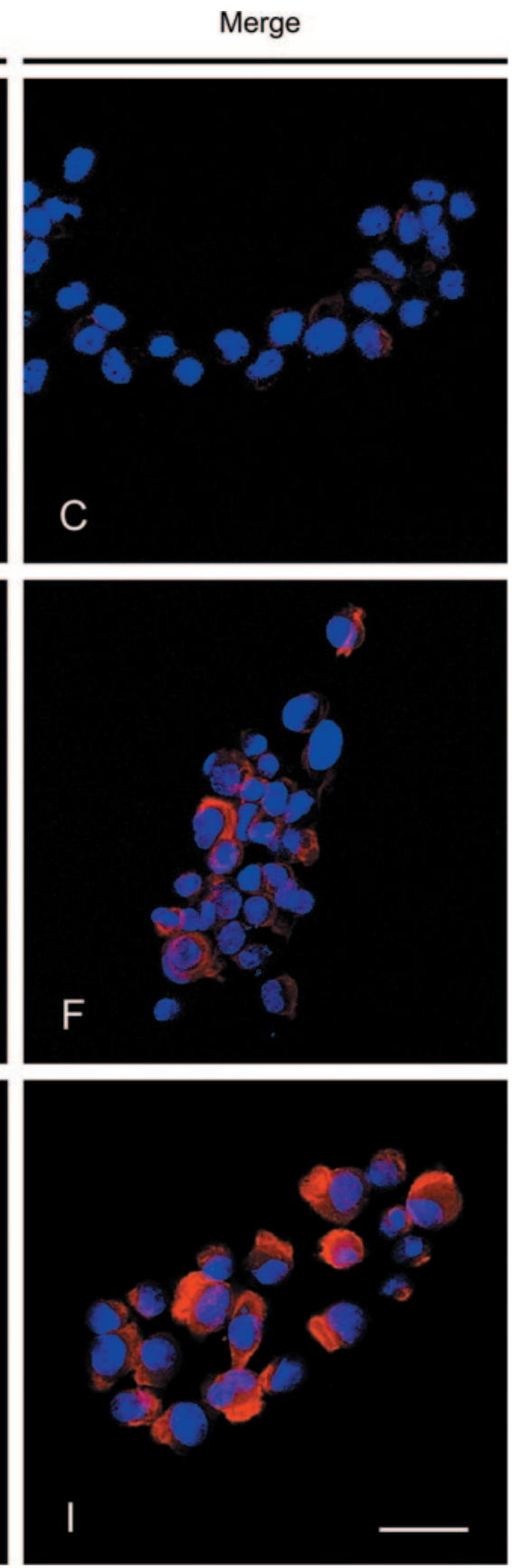

Fig. 3. Immunocytochemical analysis of ICAM-1 expression on human endothelial cells. HUVECs were stimulated with medium, LPA $(5 \mu \mathrm{M})$, or S-1-P $(5 \mu \mathrm{M})$ for $8 \mathrm{~h}$. ICAM-1 expression staining by anti-ICAM-1 FITC-conjugated monoclonal antibody is shown on left, cell nuclei stained by $4^{\prime}, 6^{\prime}$-diamidino-2-phenylindole (DAPI) are shown in middle, and merged images are given on right. All images were visualized by confocal microscopy.

shown in Figs. $1 A$ and $2 A$, top. The maximum stimulatory effects were first observed with treatment at a concentration of $0.5 \mu \mathrm{M}$ and peaked at $5 \mu \mathrm{M}$ for both LPA and S-1-P treatments. Significant increases in ICAM-1 mRNA levels were first observed as early as $1 \mathrm{~h}$ after the treatments were added, peaked at $4 \mathrm{~h}$, and decreased thereafter. These results confirmed our previous observations from DNA array experiments that both LPA and S-1-P enhance ICAM-1 mRNA expression in HUVECs.

LPA and S-1-P increase ICAM-1 protein expression. Because mRNA levels were increased by LPLs, we further investigated whether the elevated mRNA levels of ICAM-1 were also correlated to protein expression levels. The total ICAM-1 protein levels in LPL-treated cells were detected by Western blotting. After $8 \mathrm{~h}$ of treatment, both LPA and S-1-P enhanced total ICAM-1 protein expression in a concentration (Fig. 1B)- and time (Fig. 2B)-dependent manner. Consistent with the RT-PCR results, the enhancement effects of LPA and S-1-P on ICAM-1 expression in HUVECs peaked at a concentration of $5 \mu \mathrm{M}$. In the time course experiments, the enhancement effects of both LPA (Fig. 2B, top) and S-1-P (Fig. 2B, bottom) peaked at $8 \mathrm{~h}$ after treatment and decreased thereafter. 

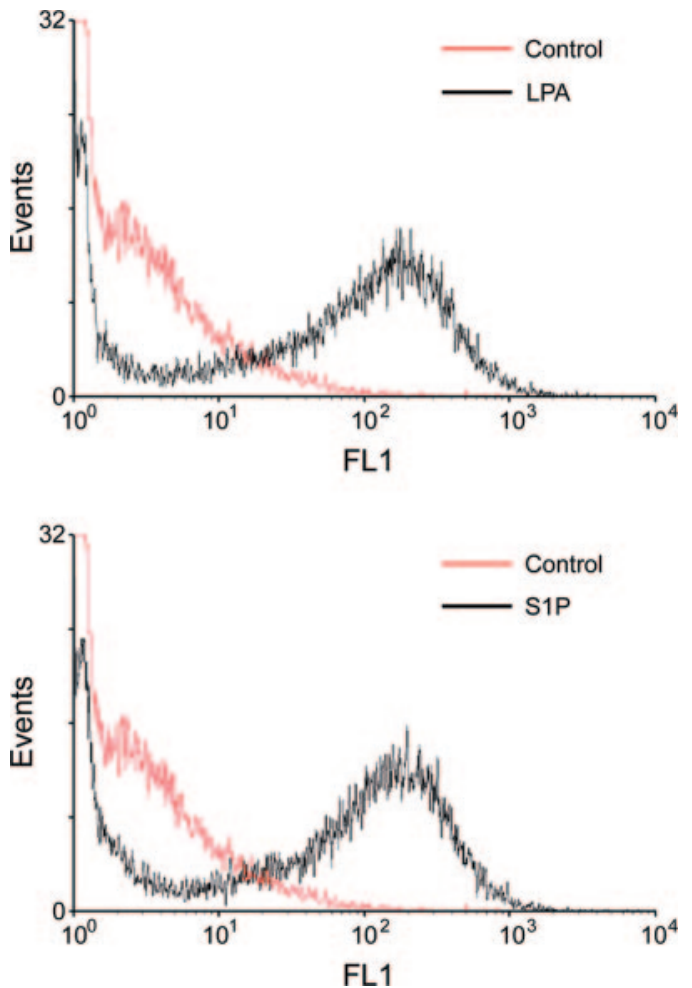

Fig. 4. LPA and S-1-P increase ICAM-1 cell surface expression on HUVECs. HUVECs were treated with $5 \mu \mathrm{M}$ LPA (top) or S-1-P (bottom) for $8 \mathrm{~h}$. Treated cells were dissociated by trypsinization. The dissociated cells were incubated with FITClabeled mouse anti-human ICAM-1 monoclonal antibody for $30 \mathrm{~min}$ and analyzed by FACscan Fluorescence label 1 (FL1) represents intensities of FITC labeling.

A
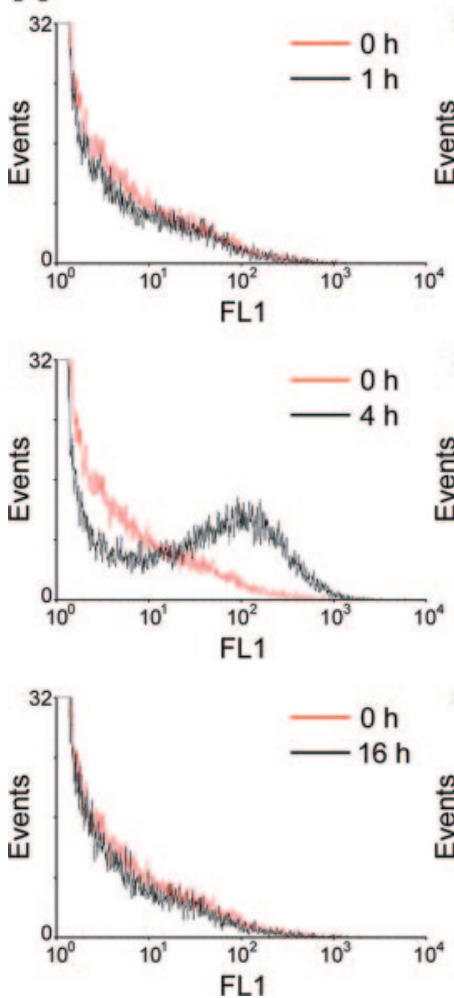
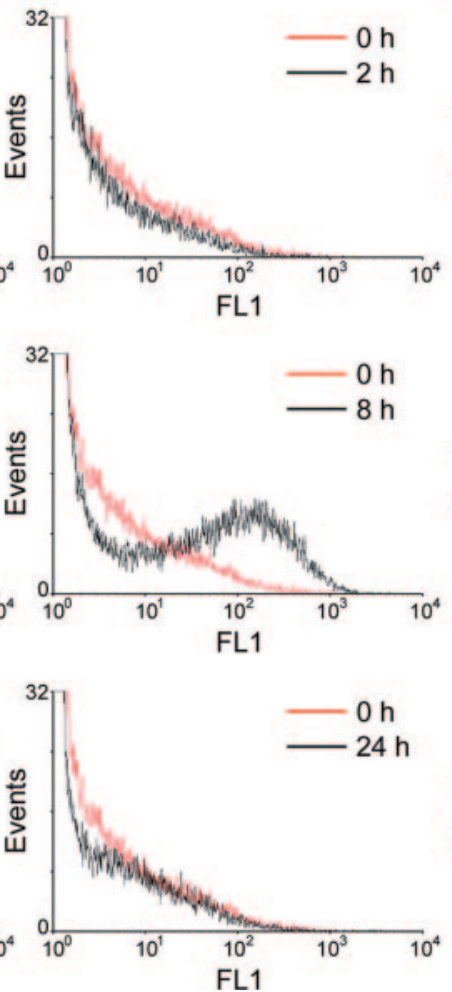

By confocal microscopy, we also observed a significant enhancement of ICAM-1 expression in LPA- and S-1-P-treated HUVECs (Fig. 3). By FACscan analysis, which detects the antigenic activities of proteins on cell surfaces, we observed a significant increase in cell-surface ICAM-1 levels in LPLtreated HUVECs (Fig. 4). These results indicated that the enhancement effects of LPLs on ICAM-1 also occur at the surface protein level, which might affect interactions between leukocytes and the endothelium during wound-healing and inflammatory processes.

In the time course experiments, we showed that both LPA (Fig. 5A) and S-1-P (Fig. 5B) enhancement of ICAM-1 protein expression on the surface of HUVECs also occurred in a time-dependent manner. LPL-enhanced HUVEC surface ICAM-1 expression was first observed at $4 \mathrm{~h}$ postligand treatment and peaked at $8 \mathrm{~h}$ postligand treatment. After $16 \mathrm{~h}$, the effects of LPL on ICAM-1 expression levels of HUVECs returned to basal levels. These results indicate that both LPA and S-1-P are potent stimulators of ICAM-1 expression on HUVECs.

$P T x, P D T C$, and BAY, but not exoC3, blocked LPA and $S$-1-P effects on ICAM-1 expression. Because LPA and S-1-P are ligands for Edg receptors, and at least three different Edg receptors are expressed on HUVECs $(26,30)$, we further investigated if the effects of LPLs on ICAM-1 expression are mediated through these receptors. We addressed this question by using chemical inhibitors known to impede signaling processes of activated Edg receptors. PTx, a specific inhibitor for $\mathrm{G}_{\mathrm{i} / \mathrm{o}}$ proteins that has been shown to inhibit $\mathrm{G}_{\mathrm{i} / \mathrm{o}}$-dependent LPL

B
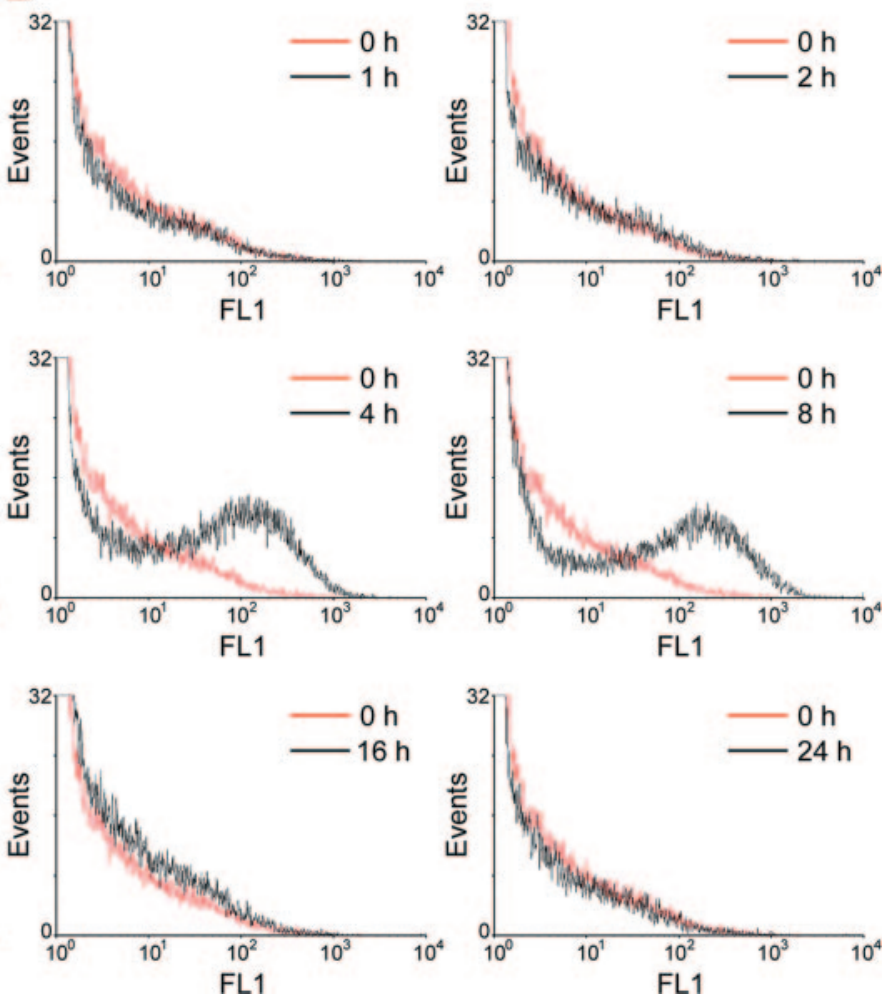

Fig. 5. LPA and S-1-P increase ICAM-1 protein levels expressed on HUVEC surfaces in a time-dependent manner. HUVECs were treated with $5 \mu \mathrm{M}$ LPA $(A)$ or S-1-P $(B)$ at various times as indicated, and treated cells were dissociated by trypsinization. The dissociated cells were incubated with FITC-labeled mouse anti-human ICAM-1 monoclonal antibody for 30 min and analyzed by FACscan. 

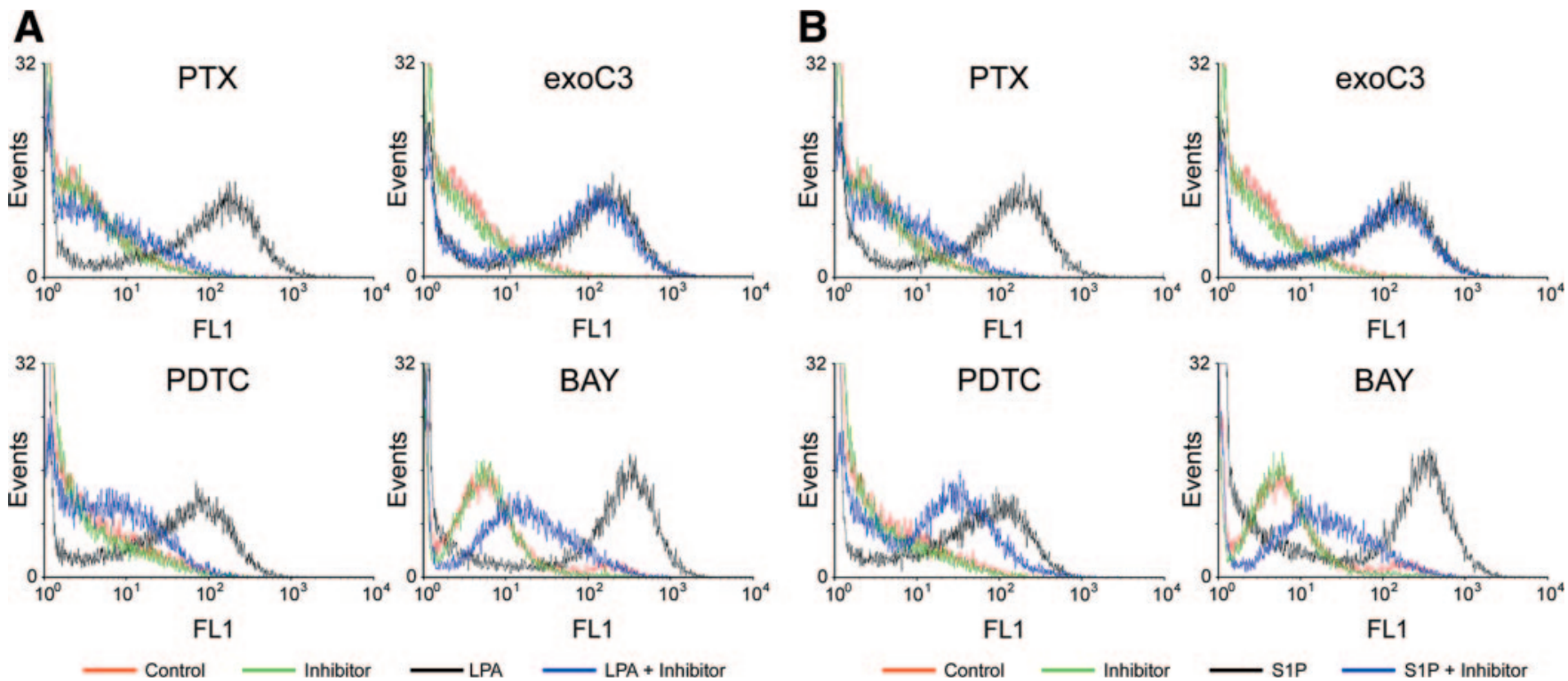

Fig. 6. LPA and S-1-P increases in ICAM-1 are mediated through a $\mathrm{G}_{\mathrm{i}-}$ and nuclear factor (NF)-кB-dependent but Rhoindependent mechanism. HUVECs were treated with control media alone, $15 \mathrm{ng} / \mathrm{ml}$ pertussis toxin (PTx), $1 \mu \mathrm{g} / \mathrm{ml} \mathrm{C} 3$ exotoxin (exoC3), $200 \mu \mathrm{M}$ PDTC, or $10 \mu \mathrm{M}$ BAY 11-7082 (BAY) for $1 \mathrm{~h}$. Treated cells were then treated with $5 \mu \mathrm{M}$ LPA $(A)$ or S-1-P $(B)$ for $8 \mathrm{~h}$. The treated cells were dissociated by trypsinization, incubated with FITC-labeled mouse anti-human ICAM-1 monoclonal antibody for $30 \mathrm{~min}$, and analyzed by FACscan.

effects in different cell systems, including HUVECs $(26,30)$, was used in our assay. Pretreatment with $15 \mathrm{ng} / \mathrm{ml} \mathrm{PTx}$ for $16 \mathrm{~h}$ had no significant effect on the basal level of ICAM-1 expression in HUVECs (Fig. 8, $A$ and $B$, top left). However, the stimulatory effects of $5 \mu \mathrm{M}$ LPA or S-1-P on ICAM-1 expression in HUVECs were totally suppressed by the toxin treatment (Fig. 6, $A$ and $B$, top left). On the other hand, pretreatment with $200 \mu \mathrm{M}$ PDTC, an inhibitor of the NF-кB-dependent pathway (8), had no effects on basal ICAM-1 expression but significantly inhibited LPL-enhanced ICAM-1 expression on HUVECs (Fig. 6, A and B, bottom left). Moreover, pretreatment with $10 \mu \mathrm{M}$ BAY, another specific inhibitor of the NF- $\kappa B$ pathway that selectively inhibits phosphorylation of inhibitory factor- $\kappa \mathrm{B}-\alpha$, had no effects on basal ICAM- 1 expression but significantly inhibited LPL-enhanced ICAM-1 expression on HUVECs (Fig. 6, $A$ and $B$, bottom right). Pretreatment with $1 \mu \mathrm{g} / \mathrm{ml}$ exoC3, a specific inhibitor of Rho (26, 30), had no effects on either basal or LPL-enhanced ICAM-1 expressions on HUVECs (Fig. 6, $A$ and $B$, top right). These results suggest that the enhancement effects of LPL on ICAM-1 expression are $\mathrm{G}_{\mathrm{i} / \mathrm{o}^{-}}$and NF- $\mathrm{kB}$-dependent, but independent of the function of Rho. Similar results were also observed at the RNA level, as detected by RT-PCR (Fig. 7).

LPA and S-1-P enhanced U-937 cell adherence to treated HUVECs. Because ICAM-1 expression on endothelial cells is responsible for their firm adhesion to leukocytes, we tested the hypothesis that LPL treatments enhance endothelial cell and monocyte adhesion by an in vitro adhesion assay. Five micromolars of LPA or S-1-P treatment on endothelial cells enhanced cell adhesion by the human monocystic cell line U-937 (Fig. 8). Furthermore, preincubation with the functional blocking antibody against human ICAM-1 significantly inhibited the enhancement effect of LPL on U-937 cell adhesion. On the contrary, a nonspecific antibody had no effects in these assays (Fig. 8, $A$ and $B$ ).

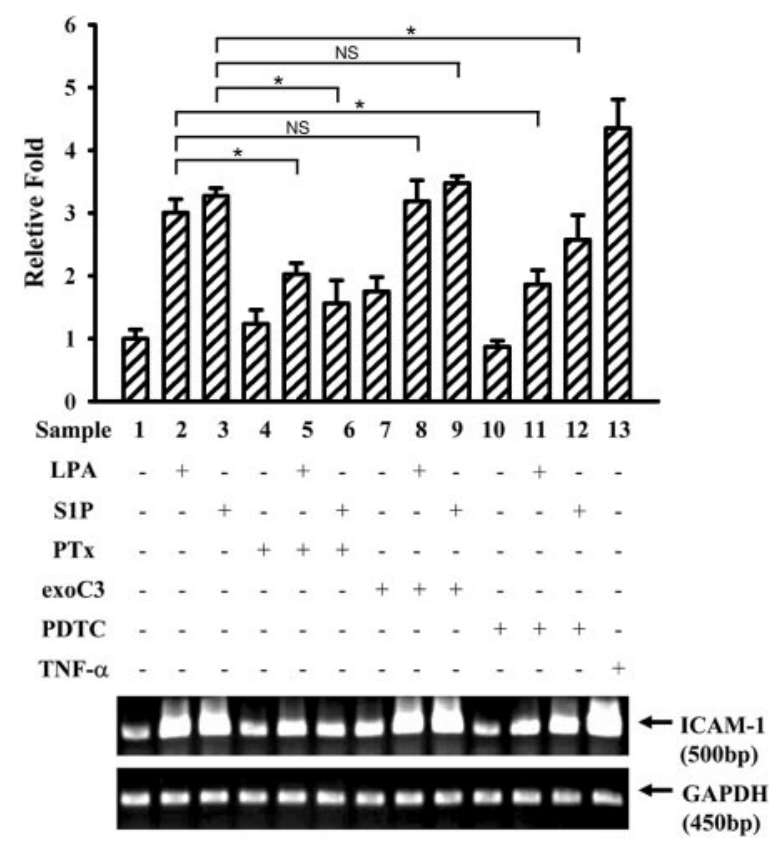

Fig. 7. Effects of a $\mathrm{G}_{\mathrm{i}}$ inhibitor (PTX), Rho inhibitor (exoC3), and NF-кB inhibitor (PDTC) on lysophospholipid (LPL)-stimulated ICAM-1 mRNA expression on HUVECs. Bottom: cells were pretreated with $15 \mathrm{ng} / \mathrm{ml}$ PTx, $1 \mu \mathrm{g} / \mathrm{ml} \mathrm{C} 3$ exotoxin, or $200 \mu \mathrm{M}$ PDTC for $1 \mathrm{~h}$, followed by LPA or S-1-P treatment for an additional $4 \mathrm{~h}$. The ICAM-1 mRNA expression level was monitored by RT-PCR. Top: histograms representing quantification by PhosphorImager of LPL-stimulated ICAM-1 mRNA expression using ImageQuaNT software $(* P<0.05)$. NS, no significance was observed. All data are relative multiples of expression compared with untreated cells. Similar experiments were repeated three times, and a representative result is shown. 

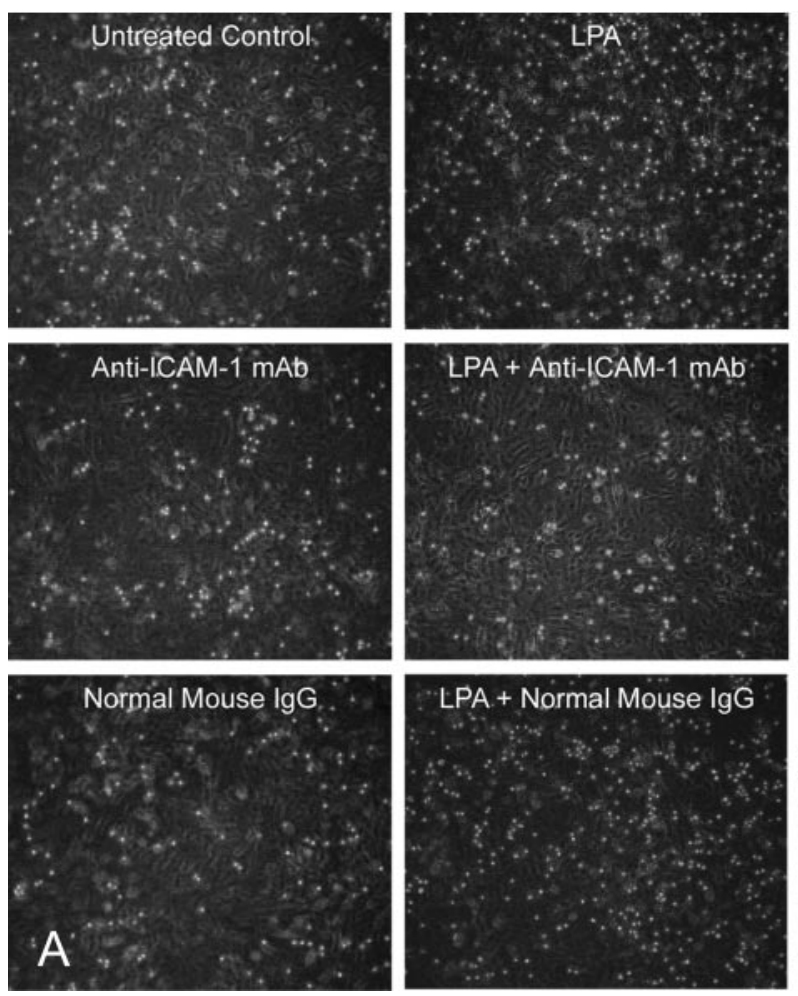
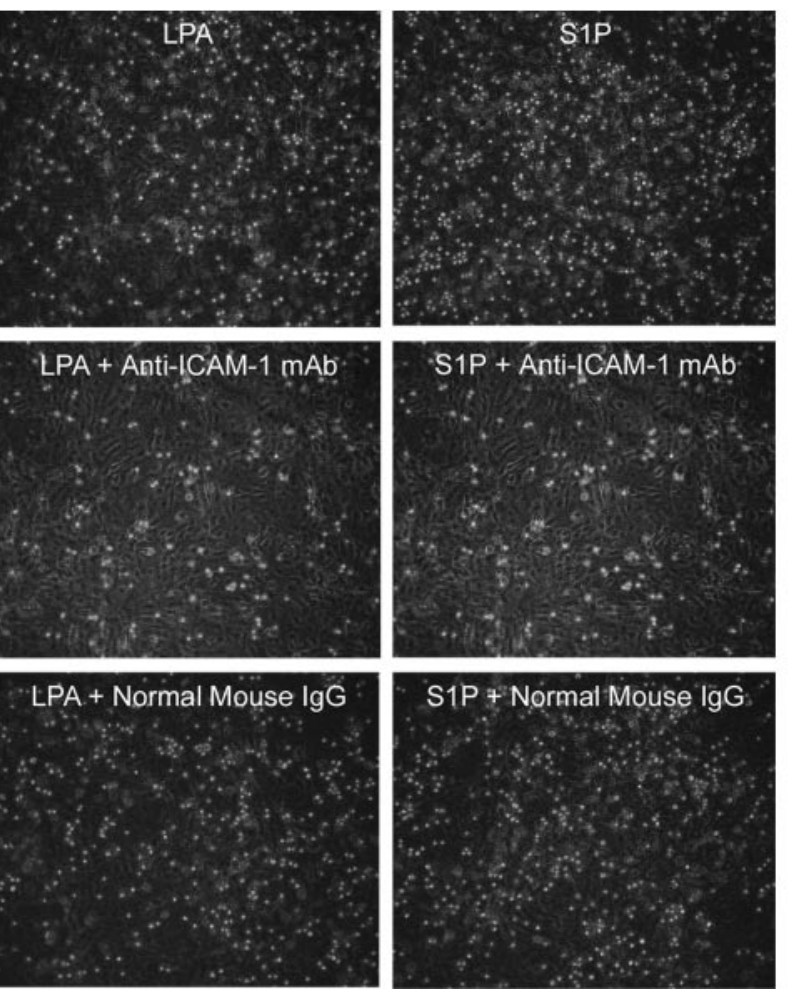

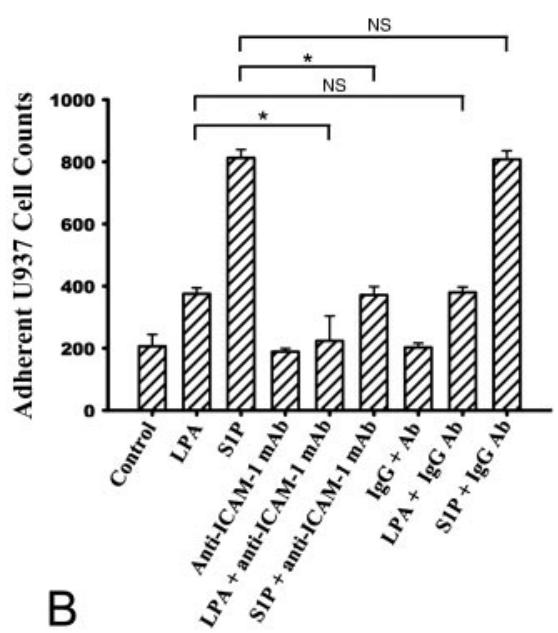

Fig. 8. LPLs enhanced U-937/HUVEC adhesion through ICAM-1 expression. A: U-937 cells stimulated with $1 \mu \mathrm{g} / \mathrm{ml} \mathrm{LPS}$ for $24 \mathrm{~h}$ were coincubated with $8 \mathrm{~h}$ medium-, LPA-, or S-1-P-stimulated HUVECs for $1 \mathrm{~h}$ in the absence or presence of ICAM-1 blocking antibody $(\mathrm{Ab})$ or normal mouse IgG. The amounts of adherent U-937 cells were monitored by microscopy. $B$ : histograms of quantification of adherent $\mathrm{U}-937$ cell counts $(* P<0.05)$. Adherent U-937 cells described in $A$ were counted by microscopy. Data are representative of 3 experiments and are expressed as means $\pm \mathrm{SE}$. mAb, monoclonal antibody.

Toxin B blocked the enhancement effects of LPA and S-1-P on ICAM-1 expression. Rac has been shown to play important roles in regulating ICAM-1 expression in human endothelial cells (1). In addition, LPA has also been shown to be able to activate Rac in neuroblastoma cells (49). Therefore, we intended to determine whether Rac also participate in the enhancement effects of LPL on ICAM-1 expression on HUVEC. Toxin B, an inhibitor of the small GTPases Rho and Rac (16), was used in our assay. Pretreatment with $0.5 \mathrm{nM}$ Toxin B for $2 \mathrm{~h}$ had no significant effect on the basal level of ICAM-1 protein expression in HUVECs, as detected by FACS. However, the stimulatory effects of $5 \mu \mathrm{M}$ LPA or S-1-P on ICAM-1 expression in HUVECs were partially suppressed by Toxin B treatment (Fig. 9). Rho has no significant effect in the stimulatory property of LPA and S-1-P on ICAM-1 expression, suggesting that Rac might be involved in the enhancement effects of these LPLs on ICAM-1 expression on HUVEC.

\section{DISCUSSION}

The results of this report show evidence that LPLs generated from activated platelets or other cell regions might enhance ICAM-1 expression by surrounding endothelial cells. Previous work suggested that LPA induces the expression of ICAM-1 on endothelial cells (35). In this report, we show that $\mathrm{S}-1-P$, an LPL that binds receptors belonging to the Edg family, has a similar effect on ICAM-1 expression on HUVECs. The enhancement effects might be mediated through a $\mathrm{G}_{\mathrm{i} / \mathrm{o}^{-}}$, NF-кB-, and Rac-dependent mechanism, which is consistent with the fact that Edg receptors activate these pathways. Furthermore, the time- and concentration-dependent activation of ICAM-1 by LPLs is also consistent with a receptor-mediated mechanism. It has been shown that both LPA and S-1-P receptors are expressed on HUVEC $(26,30)$. Therefore, the effects of LPA and $\mathrm{S}-1-P$ on these cells are expected to be mediated through these receptors.

In our previous study, we showed that LPLs are woundhealing factors in the endothelium (26). Another report also suggested that LPA facilitates wound healing in in vivo systems (3). Because ICAM-1 is an important regulator of interactions between leukocytes and endothelial cells, this suggests that the facilitating effects of LPLs on wound healing might partially be mediated through enhancement of ICAM-1 expression. From DNA array analysis and also by results reported by others, we know that LPA also enhances the expression of endothelial-leukocyte adhesion molecule (ELAM) on endothelial cells $(28,29)$. ELAM is responsible for the initial rolling effect during interactions between leukocytes and endothelial cells. These results suggest that the effects of LPLs on leukocyte-endothelial cell interactions during wound healing occur at multiple levels. This is consistent with the fact that, when tissue encounters a mechanical wound, LPLs are released from activated platelets, which might act as one of the initiating signals for the subsequent wound-healing processes.

With confocal microscopy, we also observed that LPLenhanced ICAM-1 expression formed significant capping on HUVECs. The aggregation of cell-surface molecules upon antibody cross-linking or association with other cell types has been described in several papers $(20,22)$. The capping effects 
A
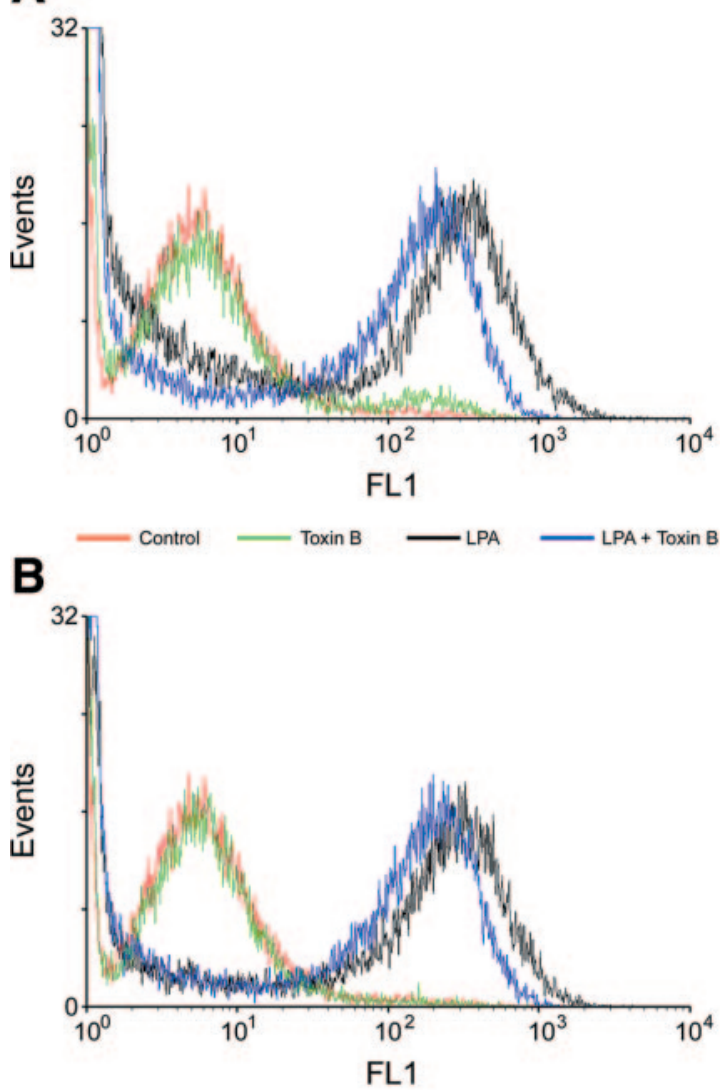

Control Toxin B $\longrightarrow$ S1P $-\$ 1 P+$ Toxin B

Fig. 9. LPA and S-1-P increases in ICAM-1 are mediated through a Racdependent mechanism. HUVECs were treated with control media alone, 0.5 $\mathrm{nM}$ Clostridium difficile toxin B for $16 \mathrm{~h}$. Treated cells were then treated with $5 \mu$ M LPA $(A)$ or S-1-P $(B)$ for $8 \mathrm{~h}$. Treated cells were dissociated by trypsinization, incubated with FITC-labeled mouse anti-human ICAM-1 monoclonal antibody for $30 \mathrm{~min}$, and analyzed by FACscan.

are likely because of surface-expressed ICAM-1 associated with the intracellular cytoskeletal structure. However, the physiological roles of this capping by adhesion molecules is currently unclear.

Activation of Rac has been shown to play important roles in regulating ICAM-1 expression in human endothelial cells (1). In addition, binding of LPA to LPA 1 also activates Rac (49). In this study, we showed that the enhancement effects of LPA and S-1-P on ICAM-1 expression in HUVECs could be partially blocked by Toxin B, an inhibitor of Rac. These results suggest that the effects of LPLs on ICAM-1 in HUVECs are at least partially mediated through Rac, which is consistent with the previous reports.

By DNA array analysis, we also observed that LPLs enhanced both IL-1 $\beta$ and TNF- $\alpha$ expression in macrophages (27). Both IL-1 $\beta$ and TNF- $\alpha$ are cytokines that regulate the blood vessel environment, specifically endothelial cell physiology. Expression of ICAM-1 on endothelial cells is also upregulated by these cytokines $(11,14)$. IL- $1 \beta$ and TNF- $\alpha$ also participate in a self-augmentation induction mechanism (10), which allows a positive-feedback mechanism to amplify the effects of these cytokines within a local milieu. Furthermore, $\mathrm{TNF}-\alpha$ directly and potently stimulates sphingosine kinase activity in HUVECs, inducing the generation of S-1-P, which further enhances endothelial and macrophage functions (53). These results suggest that platelet-derived LPLs might facilitate wound-healing processes through complex cell-cell interactions in the local environment.

It has been reported that concentrations of LPA and S-1-P in serum can reach micromolar levels (19). Therefore, it is likely that, at the wounded area, local concentration of LPLs may easily reach micromolar concentrations. The high concentration of LPLs at these wounded areas might generate a gradient of ICAM-1 expression, which is expected to peak at the spot of platelet activation. This might result in maximized leukocyteendothelial interaction at these hot spots, thereby facilitating the wound-healing process.

Hypercholesterolemia is a major risk factor for atherosclerosis. Delivery of cholesterol to HUVECs results in an increase in ICAM-1 levels (56). Upregulation of vascular cell adhesion molecule-1, ICAM-1, and E-selectin in endothelial cells by inflammatory cytokines such as vascular endothelial growth factor has also been implicated in facilitating the formation and progression of atherosclerotic plaque $(6,25)$. Abnormal expression of adhesion molecules on endothelial cells and the large amount of trans-endothelial macrophage accumulation are two of the early events in the process of atherosclerosis generation. As mentioned earlier, ICAM-1 plays a crucial role in leukocyte-endothelial cell interactions. Previous studies also indicated that ICAM-1 is an important molecule involved in atherosclerosis (51). These results strongly suggest that LPLs may play multiple roles in the process of atherosclerosis through regulating the expression of ICAM-1 and inflammatory cytokines.

Several groups have reported the effects of LPA and S-1-P on leukocyte interactions with the endothelium. In one study, S-1- $P$ inhibited neutrophil-endothelial cell interactions and subsequent neutrophil invasion (23), whereas in another report (39), LPA enhanced HL-60 cell adherence to human aortic endothelial cells. Apparent diversity of the effects of LPA and S-1-P on leukocyte-endothelial cell interaction may be attributed to the use of different leukocytes and endothelial cell types. In our report, we clearly showed that both LPA and S-1-P are potent enhancers of U-937 cell adhesion to HUVECs, and this is likely because of the enhancement of ICAM-1 expression. Our results suggest that platelet-derived LPLs enhanced leukocyte-endothelial cell interactions, consistent with the fact that they might be important regulators of the wound-healing process.

In summary, our results clearly indicate that LPLs increase ICAM-1 mRNA and protein levels in a time- and concentration-dependent manner. This induction is inhibited by specific inhibitors for NF- $\mathrm{KB}, \mathrm{G}_{\mathrm{i} / \mathrm{o}}$, and Rac. Furthermore, the enhancement effects of LPLs on ICAM-1 expression on HUVECs are responsible for augmentation of the adherence of U-937 cells to treated endothelium. Our results suggest that LPLs might be important physiological regulators of interactions between endothelial cells and mononuclear phagocytes. Therefore, these lipids might play an important role in the regulation of wound healing and possibly the generation of atherosclerosis.

\section{ACKNOWLEDGMENTS}

We thank Dr. J. H. Su Pang at Chang Gung University for technical assistance in endothelial cell culture. 


\section{GRANTS}

This work was supported by National Science Council (NSC) Grants 90-2316-B-002-019, 91-2311-B-002-071, and 92-2311-B-002-095 (to H. Lee) and partly supported by NSC Grants 92-2314-B-010-039 and 92-2314-B-010040, National Health Research Institutes Grant NHRI-EX93-9211SI (to H.-Y. $\mathrm{Hsu}$ ), and Ministry of Education Program for Promoting Academic Excellence of Universities Grant 91-B-FA09-2-4 (to H.-Y. Hsu and H. L. Wu).

\section{REFERENCES}

1. Ahmad M, Zhang Y, Zhang Y, Papharalambus C, and Alexander RW. Role of isoprenylcysteine carboxyl methyltransferase in tumor necrosis factor-alpha stimulation of expression of vascular cell adhesion molecule-1 in endothelial cells. Arterioscler Thromb Vasc Biol 22: 759 764, 2002.

2. An S, Goetzl EJ, and Lee H. Signaling mechanisms and molecular characteristics of $\mathrm{G}$ protein-coupled receptors for lysophosphatidic acid and sphingosine 1-phosphate. J Cell Biochem 30: 147-157, 1998.

3. Balazs L, Okolicany J, Ferrebee M, Tolley B, and Tigyi G. Topical application of the phospholipid growth factor lysophosphatidic acid promotes wound healing in vivo. Am J Physiol Regul Integr Comp Physiol 280: R466-R472, 2001

4. Bayless KJ and Davis GE. Sphingosine-1-phosphate markedly induces matrix metalloproteinase and integrin-dependent human endothelial cell invasion and lumen formation in three-dimensional collagen and fibrin matrices. Biochem Biophys Res Commun 312: 903-913, 2003.

5. Chun J, Cantos JJ, and Munroe D. A growing family of receptor genes for lysophosphatidic acid (LPA) and other lysophospholipids (LPs). Cell Biochem Biophys 30: 213-242, 1999.

6. Costanzo A, Moretti F, Burgio VL, Bravi C, Guido F, Levrero M, and Puri PL. Endothelial activation by angiotensin II through NFkappaB and p38 pathways: Involvement of NFkappaB-inducible kinase (NIK), free oxygen radicals, and selective inhibition by aspirin. J Cell Physiol 195: 402-410, 2003.

7. Crook MF, Southgate KM, and Newby AC. Both ICAM-1- and VCAM1-integrin interactions are important in mediating monocyte adhesion to human saphenous vein. J Vasc Res 39: 221-229, 2002.

8. Da Silva CA, Heilbock C, Kassel O, and Frossard N. Transcription of stem cell factor (SCF) is potentiated by glucocorticoids and interleukin- $1 \beta$ through concerted regulation of a GRE-like and an NF- $\kappa \mathrm{B}$ response element. FASEB J 17: 2334-2336, 2003.

9. Davies MJ, Gordan JL, Gearing AJH, Pigott R, Woolf N, Katz D, and Kyriakopoulos A. The expression of the adhesion molecules ICAM-1, VCAM-1, PECAM and E-selectin in human atherosclerosis. J Pathol 171: 223-229, 1993.

10. Dinarello C. Interleukin-1 and its biologically related cytokines. $A d v$ Immunol 44: 153-205, 1989.

11. Dustin ML, Rothlein R, Marlin SD, and Sprinter TA. A natural adherence molecule (ICAM-1): induction by IL-1 and IFN-g. Tissue distribution, biochemistry and function. J Immunol 137: 245-254, 1986.

12. Eichholtz T, Jalink K, Fahrenfort I, and Moolenaar WH. The bioactive phospholipid lysophosphatidic acid is released from activated platelets. Biochem J 291: 677-680, 1993.

13. Essler M, Retzer M, Bauer M, Zangl K, Tigyi G, and Siess W. Stimulation of platelets and endothelial cells by mildly oxidized LDL proceeds through activation of lysophosphatidic acid receptors and the Rho/Rho-kinase pathway. Inhibition by lovastatin. Ann NY Acad Sci 905: 282-286, 2000.

14. Fan J, Shimokama T, Haraoka S, Tokunaga O, and Watanabe T. Monocyte-endothelial cell interactions in vitro, with reference to the influence to the influence of interleukin-1 and tumor necrosis factor. Biol Cell 79: 17-26, 1993

15. Folkman J and Shing Y. Angiogenesis. J Biol Chem 267: 10931-10934, 1992.

16. Garrett WS, Chen LM, Kroschewski R. Developmental control of endocytosis in dendritic cells by Cdc42. Cell 102: 325-334, 2000.

17. Garrity RG. The role of the monocyte in atherogenesis. I. Transition of blood-borne monocytes into foam cells in fatty lesions. Am J Pathol 103: 181-199, 1981.

18. Goetzl EJ and An S. Diversity of cellular receptors and functions for the lysophospholipid growth factors lysophosphatidic acid and sphingosine 1-phosphate. FASEB J 12: 1589-1598, 1998.
19. Goetzl EJ, Graeler M, Huang MC, and Shankar G. Lysophospholipid growth factors and their $\mathrm{G}$ protein-coupled receptors in immunity, coronary artery disease, and cancer. Scientific World Journal 2: 324-338, 2002.

20. Haverstick DM, Sakai H, and Gray LS. Lymphocyte adhesion can be regulated by cytoskeleton-associated, PMA-induced capping of surface receptors. Am J Physiol Cell Physiol 262: C916-C926, 1992.

21. Hla T, Lee MJ, Ancellin N, Liu CH, Thangada S, Thompson BD, and Kluk M. Sphingosine-1-phosphate: extracellular mediator or intracellular second messenger? Biochem Pharmacol 58: 201-207, 1999.

22. Junge S, Brenner B, Lepple-Wienhues A, Nilius B, Lang F, Linderkamp O, and Gulbins E. Intracellular mechanisms of L-selectin induced capping. Cell Signal 11: 301-308, 1999.

23. Kawa S, Kimura S, Hakomori S, and Igarashi Y. Inhibition of chemotactic motility and trans-endothelial migration of human neutrophils by sphingosine 1-phosphate. FEBS Lett 420: 196-200, 1997.

24. Khan BV, Parthasarathy S, Alexander RW, and Madford RM. Modified low density lipoprotein and its constituents augment cytokine-activated vascular cell adhesion molecule-1 gene expression in human vascular endothelial cells. J Clin Invest 95: 1262-1270, 1995.

25. Kim I, Moon SO, Kim SH, Kim HJ, Koh YS, and Koh GY. Vascular endothelial growth factor expression of intercellular adhesion molecule 1 (ICAM-1), vascular cell adhesion molecule 1 (VCAM-1), and E-selectin through nuclear factor-kappa B activation in endothelial cells. J Biol Chem 276: 7614-7620, 2001.

26. Lee H, Goetzl EJ, and An S. Lysophosphatidic acid and sphingosine 1-phosphate stimulate endothelial cell wound healing. Am J Physiol Cell Physiol 278: C612-C618, 2000.

27. Lee H, Liao JJ, Graeler M, Huang MC, and Goetzl EJ. Lysophospholipid regulation of mononuclear phagocytes. Biochim Biophys Acta 1582: 175-177, 2002.

28. Lee MJ, Thangada S, Claffey KP, Ancellin N, Liu CH, Kluk M, Volpi M, Sha'afi RI, and Hla T. Vascular endothelial cell adherens junction assembly and morphogenesis induced by sphingosine-1-phosphate. Cell 99: 301-312, 1999.

29. Lee OH, Kim YM, Lee YM, Moon EJ, Lee DJ, Kim JH, Kim KW, and Kwon YG. Sphingosine 1-phosphate induces angiogenesis: its angiogenic action and signaling mechanism in human umbilical vein endothelial cells. Biochem Biophys Res Commun 264: 743-750, 1999.

30. Lee OH, Lee DJ, Kim YM, Kim YS, Kwon HJ, Kim KW, and Kwon YG. Sphingosine 1-phosphate stimulates tyrosine phosphorylation of focal adhesion kinase and chemotactic motility of endothelial cells via the G(i) protein-linked phospholipase C pathway. Biochem Biophys Res Commun 268: 47-53, 2000.

31. Liu Y, Wada R, Yamashita T, Mi Y, Deng CX, Hobson JP, Rosenfeldt HM, Nava VE, Chae SS, Lee MJ, Liu CH, Hla T, Spiegel S, and Proia RL. Edg-1, the G protein-coupled receptor for sphingosine-1-phosphate, is essential for vascular maturation. J Clin Invest 106: 951-961, 2000.

32. Maschberger P, Bauer M, Baumann-Siemons J, Zangl KJ, Negrescu EV, Reininger AJ, and Siess W. Mildly oxidized low density lipoprotein rapidly stimulates via activation of the lysophosphatidic acid receptor Src family and Syk tyrosine kinases and $\mathrm{Ca} 2+$ influx in human platelets. J Biol Chem 275: 19159-19166, 2000.

33. Moolenaar WH. Lysophosphatidic acid, a multifunctional phospholipid messenger. J Biol Chem 270: 12949-12952, 1995.

34. Moolenaar WH. Bioactive lysophospholipids and their $\mathrm{G}$ protein-coupled receptors. Exp Cell Res 253: 230-238, 1999.

35. Palmetshofer A, Robson SC, and Nehls V. Lysophosphatidic acid activates nuclear factor kappa $\mathrm{B}$ and induces proinflammatory gene expression in endothelial cells. Thromb Haemost 82: 1532-1537, 1999.

36. Panetti TS, Chen H, Misenheimer TM, Getzler SB, and Mosher DF. Endothelial cell mitogenesis induced by LPA: inhibition by thrombospondin-1 and thrombospondin-2. J Lab Clin Med 129: 208-216, 1997.

37. Panetti TS, Magnusson M, Peyruchaud O, Zhang Q, Cooke M, Sakai T, and Mosher D. Modulation of cell interactions with extracellular matrix by lysophosphatidic acid and sphingosine 1-phosphate. Prostagl Other Lipid Mediat 64: 93-106, 2001.

38. Pierce JW, Schoenleber R, and Jesmok G. Novel inhibitors of cytokineinduced I $\mathrm{B} \alpha$ phosphorylation and endothelial cell adhesion molecule expression show anti-inflammatory effects in vivo. J Biol Chem 272: 21096-21103, 1997.

39. Rizza C, Leitinger N, Yue J, Fischer D, Wang D, Shih P, Lee H, Tigyi G, and Berliner J. Lysophosphatidic acid as a regulator of endothelial/ leukocyte interaction. Lab Invest 79: 1227-1235, 1999. 
40. Ross R. Atherosclerosis-an inflammatory disease. $N$ Engl J Med 340: 115-126, 1999.

41. Samlley DM, Lin JHC, Curtis ML, Kobari Y, Stemerman MB, and Prichard KA Jr. Native LDL increases endothelial cell adhesiveness by inducing intercellular adhesion molecule-1. Arterioscler Thromb Vasc Biol 16: 585-590, 1996.

42. Siess W, Zangl K, Essler M, Bauer M, Brandl R, Corrinth C, Bittman R, Tigyi G, and Aepfelbacher M. Lysophosphatidic acid mediates the rapid activation of platelets and endothelial cells by mildly oxidized low density lipoprotein and accumulates in human atherosclerotic lesions. Proc Natl Acad Sci USA 96: 6931-6936, 1999.

43. Shen Z, Belinson J, Morton RE, and Xu Y. Phorbol 12-myristate 13-acetate stimulates lysophosphatidic acid secretion from ovarian and cervical cancer cells but not from breast or leukemia cells. Gynecol Oncol 71: 364-368, 1998.

44. Spiegel S, Cuvillier O, Edsall LC, Kohama T, Menzeleev R, Olah Z, Olivera A, Pirianov G, Thomas DM, Tu Z, Van Brocklyn JR, and Wang F. Sphingosine-1-phosphate in cell growth and cell death. Ann NY Acad Sci 845: 11-18, 1998.

45. Spiegel $\mathbf{S}$ and Milstien S. Functions of a new family of sphingosine-1phosphate receptors. Biochim Biophys Acta 1484: 107-116, 2000.

46. Tokumura A. A family of phospholipid autacoids: occurrence, metabolism and bioactions. Prog Lipid Res 34: 151-184, 1995.

47. Valet $\mathbf{P}$, Pagès $\mathbf{C}$, Jeanneton $\mathbf{O}$, Daviaud $\mathbf{D}$, Barbe $\mathbf{P}$, Record $\mathbf{M}$, Saulnier-Blache JS, and Lafontan M. Alpha2-adrenergic receptor-mediated release of lysophosphatidic acid by adipocytes. A paracrine signal for preadipocyte growth. J Clin Invest 101: 1431-1438, 1998.

48. Van der Wal AC, Das PK, Tigges AJ, and Becker AL. Adhesion molecules on the endothelium and mononuclear cells in human atherosclerotic lesions. Am J Pathol 141: 1427-1433, 1992.
49. Van Leeuwen FN, Olivo C, Grivell S, Giepmans BN, Collard JG, and Moolenaar WH. Rac activation by lysophosphatidic acid $\mathrm{LPA}_{1}$ receptors through the guanine nucleotide exchange factor Tiam1. J Biol Chem 278: 400-406, 2003.

50. Wang F, Van Brocklyn JR, Hobson JP, Movafagh S, ZukowskaGrojec Z, Milstien S, and Spiegel S. Sphingosine 1-phosphate stimulates cell migration through a G(i)-coupled cell surface receptor. Potential involvement in angiogenesis. J Biol Chem 274: 35343-15350, 1999.

51. Watanabe T and Fan J. Atherosclerosis and inflammation mononuclear cell recruitment and adhesion molecules with reference to the implication of ICAM-1/LFA-1 pathway in atherogenesis. Int J Cardiol 66, Suppl 1: S45-S53, 1998.

52. Watsky MGM, Wang DA, and Tigyi GJ. Phospholipid growth factors and corneal wound healing. Ann NY Acad Sci 905: 142-158, 2000.

53. Xia P, Gamble J, Rye K, Wang L, Hii C, Cockerill P, Khew-Goodall Y, Bert A, Barter P, and Vadas M. Tumor necrosis factor-alpha induces adhesion molecule expression through the sphingosine kinase pathway. Proc Natl Acad Sci USA 95: 14196-14201, 1998.

54. Xu Y, Shen Z, Wiper DW, Wu M, Morton RE, Elson P, Kennedy AW, Belinson J, Markman M, and Casey G. Lysophosphatidic acid as a potential biomarker for ovarian and other gynecologic cancers. JAMA 280: 719-723, 1998.

55. Yatomi Y, Igarashi Y, Yang L, Hisano N, Qi R, Asazuma N, Satoh K, Ozaki Y, and Kume S. Sphingosine 1-phosphate, a bioactive sphingolipid abundantly stored in platelets, is a normal constituent of human plasma and serum. J Biochem (Tokyo) 121: 969-973, 1997.

56. Yuan Y, Verna LK, Wang NP, Liao HL, Ma KS, Wang Y, Zhu Y, and Stemerman MB. Cholesterol enrichment upregulates intercellular adhesion molecule-1 in human vascular endothelial cells. Biochim Biophys Acta 1534: 139-148, 2001.

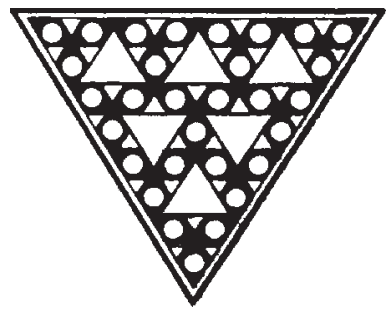

